\title{
Chapter 20 \\ Researching Links Between Teacher Wellbeing and Educational Change: Case Studies from Kazakhstan and Sakha Republic
}

\author{
Olga M. Chorosova and Nikolai F. Artemev
}

\begin{abstract}
Many issues about teacher evaluation have been discussed in Russia where evaluation procedures are constantly under review as the teachers seek continuous improvement. This chapter contributes to this discussion, first, by adding a wider international perspective, secondly, by exploring the experiences of participants (observers, in-service teachers) and, finally, by drawing on research related to teacher evaluation. The authors present the outcomes of the survey conducted among teachers in Russia's Sakha Republic (Yakutia) and in the Republic of Kazakhstan. The research objectives were: evaluation of the adaptation process in professional and personal development of in-service teachers caused by changes in education system of Russia and the development of basic professional competences of teachers. The study aimed to explore the views of teachers and analyses of teacher evaluation via a mixed-method approach. The rationale for this study was born out of the disillusionment with teacher evaluation. Therefore, it was concluded that existing evaluation practices may need to be examined to see if they serve the best interests of teachers.
\end{abstract}

\subsection{Introduction}

Yakutia and Kazakhstan share common Soviet past and have presently similar state of education (Chorosova et al. 2006). At different stages of its development, Russian educational system has experienced processes of modernization; at different times attempts were made to reform it so that at this stage we can talk about systemic changes which are understood as a transformation of the educational space. Excerpts from the Professional Standard show conclusively the relationship between the moral side of a teacher's professional activity and emotional-volitional part of his or her personality as it is only a teacher who is capable of spiritual and moral reflection

O.M. Chorosova $(\bowtie) \cdot$ N.F. Artemev

Ammosov North-Eastern Federal University,

58 Belinsky St, Yakutsk 677000, Russian Federation

e-mail: chorosovaom@mail.ru; nf.artemev@s-vfu.ru 
and widely accepting continuous self-improvement and lifelong education. A teacher who can reveal to students strategies of life and tactics of self-improvement, and provide professional and pedagogical help in designing their personal development (Asmolov 1996). At the basis of this activity is the ability of teachers to spiritually and morally improve their personality, which has a limitless potential by such cognitive indicators as: (1) the volume of knowledge on morality, its connection to spirit and spirituality; (2) consistency of this knowledge; (3) its meaningfulness; (4) its stability; (5) its creative use in life. All of the above makes the issue of basic professional competencies of a teacher extremely relevant (Amabile 1982). In the beginning of 2000s, the Russian society started to overcome the negative tendencies of the crisis of the end of the 1990s. The pedagogical society was experiencing an emotional uplift, the feeling of a certain stability in social and economic context began to dominate. The beginning of 2000s was characterised by an unprecedented innovative boom in the education of the republic, which started actively integrate into the international open educational environment. This probably accounts for the highest value of the openness to the world factor in 2005 (Chorosova et al. 2006).

\subsection{Problem Statement}

The literature on teachers' evaluations were carefully studied. One of the objectives of this study was to understand how teachers are evaluated and supported throughout their careers but there were some consequent problems (Howard and Donaghue 2015). Before describing how the study was conducted, an overview is given to pertinent themes emanating from literature on this area of concern.

The main problem is a rise in managerialism in education that leads to "extra scrutiny" since people want proof of teachers' effectiveness (Deem 2003). Deem (2003) suggests a more negative perception which focuses on functions, tasks and behaviors. This has institutions to become linemanaged entities where 'professionals are subjected to a rigorous regime of external accountability in which continuous monitoring and audit of performance and quality are dominant' (Deem 2003, pp. 57-58). Kydd (1997) summarizes the conflict effectively by suggesting that 'the intensification of management controls is replacing the wisdom, experience, and self-monitoring of the practitioner' (p. 116).

The focus was on problems related to evaluation of in-service teachers. While such monitoring may be familiar in pre-service teacher training, for experienced teachers it may be more stressful (Howard and McCloskey 2001) as they might feel that the survey questions interfere with their professionalism and that is inappropriate. According to Howard and McCloskey, major reasons for an aversion to evaluation are the sense that it does not promote professional growth and its accountability and prescriptive conformity which may conflict with a teacher's desire for professional autonomy (Fullan 2007). Quality assurance (QA) is defined by its adherence to measurable standards and outcomes. An education has become an international enterprise, and the need to ensure that trans-border standards are met has magnified 
its importance (Aubrey and Coombe 2011). QA obliges practitioners to focus on teaching curricula efficiently and effectively (Kydd 1997). However, there are certain precautions to consider its successful implementation.

This study aimed to explore, via a mixed-method approach, the views of experienced teachers and analysts on teacher evaluation. The rationale for this study was born out of our own disillusionment with teacher evaluation. Therefore, the existing evaluation practices may need to be examined to see if they serve the best interests of experienced teachers. To achieve this, following research questions were designed: What is the quality of professional and personal wellbeing of teachers? How to diagnose and prevent reasons of emotional burnout of teachers? How to define ways of reducing crisis factors' influence on northern teacher staff's mass exodus? What are the views of experienced teachers regarding teacher evaluation? What are the views of analysts regarding teacher evaluation? The answers to these questions allowed to find a scientific understanding of staff turnover and to define ways of reducing crisis factors' influence on northern teachers and on teachers' emotional burnout. The study of the role of renewal processes and crisis factors of professional and personal wellbeing of teachers, revealing the qualification gaps of teachers through the assessment of professional competences and abilities, will improve teachers' assessment of the quality of life. The strong belief was that the sources of motivation in the professional and personal development of teachers, integrating in creative activities to create innovative projects were curiosity and interest, setting learning goals and belief in self-efficacy. Specifying the structure of creative teaching activities, V.A. Kan-Kalik and N.D. Nikandrov defined the following sequence of its stages: the emergence of the pedagogical plan aimed at addressing educational problems; concept development; the embodiment of the pedagogical design in activities, in dealing with people; analysis and evaluation of the results of the creative process (Kan-Kalik and Nikandrov 1990). The concept of "creativity" was used by S.L. Rubinstein as "contagion" - as creation of new, original case with social significance; as the creation of something new, including in the inner world of the subject (Rubinstein 2006). The environment, in which the Northern teacher can develop creatively, should have a high degree of uncertainty and potential multivariance (wealth of opportunities). Uncertainty encouraged the search for persons own benchmarks rather than the adoption of what's ready; multi-variance made it possible to find them.

\subsection{Methods}

A quantitative analysis was required to identify how current teachers overcome obstacles and challenges created by constant stream of changes in the national system of education both in Russian Yakutia and in Kazakhstan. In this study, surveys of 2005, 2015, and 2016 were used. An online questionnaire was developed on the university website platform. The goal was to reveal how teachers face negativity of crisis factors and find ways to continue personal professional development. 


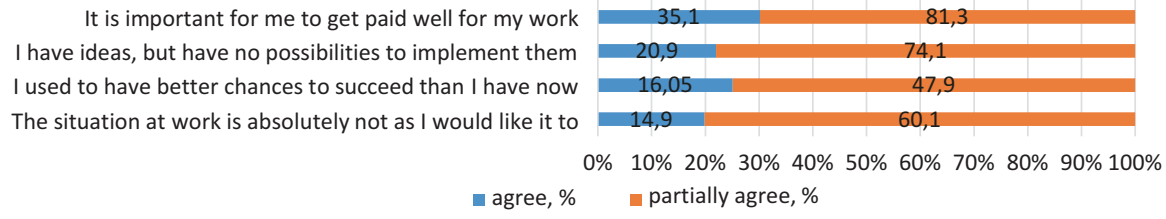

Fig. 20.1 Results of Yakutia survey

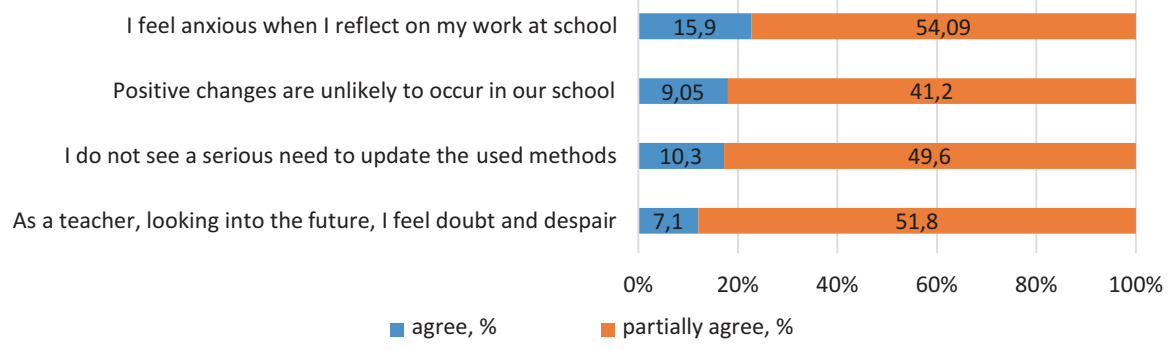

Fig. 20.2 Results of Yakutia survey

\subsection{Results}

In total, over 1000 in-service teachers of the Sakha Republic (Yakutia) and 2389 in-service teachers of Kazakhstan were surveyed. Both results were compared and analyzed. Teachers of Yakutia (Figs. 20.1 and 20.2) describe the presence of crisisproducing factors. Individuals in a crisis tend to have higher values for these factors. Such individuals are alienated from others and believe that nobody understand them well that external circumstances dictate their life and that they are not able to determine their own lives. They cannot see the meaning of their life, their inner hierarchy of values disintegrated, things that seemed important on a regular basis changed and they cannot decide what is important and what is not. Such individuals are no longer interested in something new and do not seek to develop themselves. It is important to pay attention to the rate of values, which have the highest points relatively to other factors.

Figures 20.3 and 20.4 describe the presence of factors that help to overcome crises in Yakutia survey results. Individuals in a stable condition overcome a crisis and tend to have high values for these factors. Individuals who overcome the crisis are open to people, to the world and they care about not only their own problems but also problems of others and seek to resolve them.

Such individuals constantly educate themselves (Fig. 20.4), work on personal development and are interested in new information. All this allows them to better understand themselves and to set clear goals, make decisions and follow them. Such individuals acquire self-control; they overcome external circumstances and use their 
In order to teach children a person must be aware of the different aspects of life

I know many examples of people who cope with the issue of self-realization in the profession perfectly well I like discovering new vision of things, a different standpoint

I want to understand life better and feel more

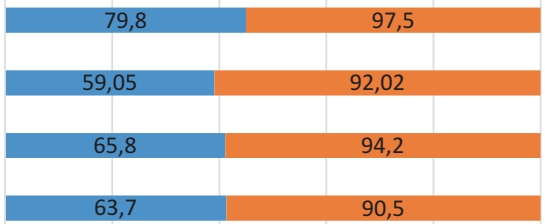

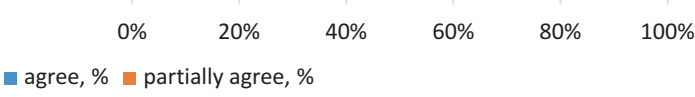

Fig. 20.3 Factor of orientation towards something new, intent for development (Yakutia)

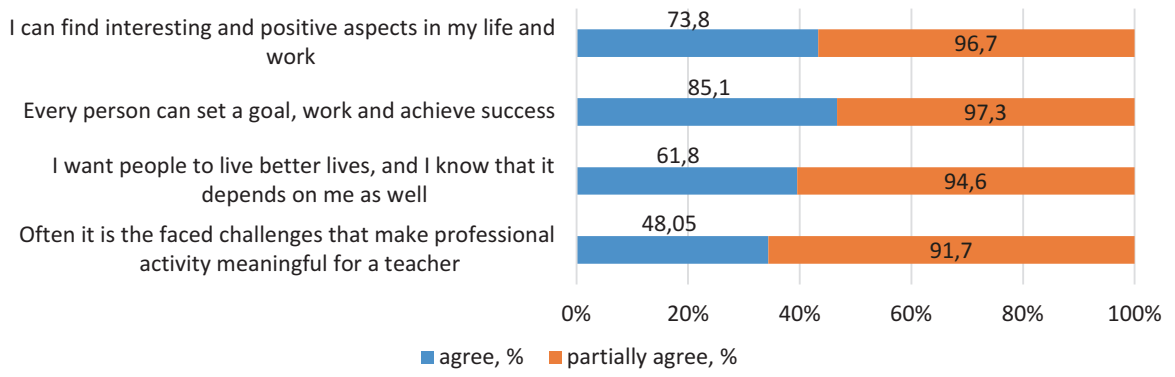

Fig. 20.4 Factor of setting goals (Yakutia)

capacities. It is important to pay attention to the rate of values, which have the lowest points relatively to other factors of overcoming crises. Figures show the representation of a crisis-prone factors in the lives of teachers, clearly show the state of depression, confusion and anxiety in a greater or lesser extent. For instance, $41.2 \%$ to $54.09 \%$ of Yakutian teachers have the lack of dignity in professional career. $47.9 \%$ to $81.3 \%$ of teachers are affected by the influence of external negative circumstances, the inability to implement their plans and prioritize high payment for their work experience. $32.1 \%$ to $67.4 \%$ of teachers have the sense of loss of meaning in life. $28.1 \%$ to $60.8 \%$ have the feeling of loneliness and alienation. This suggests that teachers respond to unfavorable trends of our times as sensitive indicators of the state of society, primarily due to the fact that this state of society is reflected and refracted in children. However at the same time, the outcomes of this survey showed a very high resistance (from $90.5 \%$ to $97.5 \%$ ) to the effects of a crisis-prone factors accompanied by exceptional adaptability to the adverse social factors and the adaptability to the rapidly changing world and society when there is a need to react quickly and learn fast. Teachers of the North are characterized with a desire to everything new and tolerant attitude, self-control when necessary and selfregulation. $72.6 \%$ to $95.7 \%$ responses confirm it. Yakutian teachers are aware of the importance of goal-setting skills, when setting more and more new purposes becomes an internal necessity of constantly developing personality: $91.7 \%-97.3 \%$. A developing personality can be curious, indifferent, open to everything new and unknown at every moment of life. For the analysis of Yakutia and Kazakhstan, it is 
Table 20.1 The effect of crisis factors on the teachers of Kazakhstan

\begin{tabular}{l|l|l|l|l|l|l|l}
\hline A & B & C & D & E & F & G & H \\
\hline $\begin{array}{l}\text { Lack of } \\
\text { future } \\
\text { prospects }\end{array}$ & $\begin{array}{l}\text { External } \\
\text { circums- } \\
\text { tances }\end{array}$ & $\begin{array}{l}\text { Lose of } \\
\text { reasons } \\
\text { for living }\end{array}$ & alienation & $\begin{array}{l}\text { Desire to new, } \\
\text { intense to } \\
\text { self-development }\end{array}$ & $\begin{array}{l}\text { Gaining } \\
\text { self- } \\
\text { control }\end{array}$ & $\begin{array}{l}\text { gaining } \\
\text { goals }\end{array}$ & $\begin{array}{l}\text { Openness } \\
\text { towards } \\
\text { the world }\end{array}$ \\
\hline 0.42 & 0.45 & 0.37 & 0.35 & 0.7 & 0.6 & 0.77 & 0.75 \\
\hline
\end{tabular}

0 - negative answer, 1 - affirmative answer

Table 20.2 Sakha Republic (Yakutia), 2005

\begin{tabular}{l|l|l|l|l|l|l|l}
\hline A & B & C & D & E & F & G & H \\
\hline $\begin{array}{l}\text { Lack of } \\
\text { future } \\
\text { prospects }\end{array}$ & $\begin{array}{l}\text { External } \\
\text { circums- } \\
\text { tances }\end{array}$ & $\begin{array}{l}\text { Lose of } \\
\text { reasons } \\
\text { for living }\end{array}$ & alienation & $\begin{array}{l}\text { Desire to new, } \\
\text { intense to } \\
\text { self-development }\end{array}$ & $\begin{array}{l}\text { Gaining } \\
\text { self- } \\
\text { control }\end{array}$ & $\begin{array}{l}\text { gaining } \\
\text { goals }\end{array}$ & $\begin{array}{l}\text { Openness } \\
\text { towards } \\
\text { the world }\end{array}$ \\
\hline 0.3 & 0.5 & 0.6 & 0.6 & 0.8 & 0.8 & 0.8 & 0.9 \\
\hline
\end{tabular}

0 - negative answer, 1 - affirmative answer

necessary to clarify that selected identical corresponding questions were selected in materials of Kazakhstan colleagues. In identifying crisis factors, it was important to focus on the representation of those of them whose values are at a maximum compared to other factors. During the data analysis, it showed that for Kazakhstan teachers a potential crisis state can be triggered by the influence of external circumstances (Zh. O. Zhilbaev. National Academy of Education). In the Kazakhstan community of teachers, the choice of a behavioural pattern not only in a professional sphere but also in a personal life is often influenced by public opinion. The outcomes revealed that the indicators of all four crisis factors have low values, which show that there is no crisis state; the other three factors (lack of future prospects, losing one's reasons for living, alienation) that represent a serious psychological problem and are potentially dangerous for the society are minimal ( $0.4-0.5$ points). In identifying factors responsible for overcoming crises, it was important to pay a special attention to those of them, whose values are at a maximum compared to other factors. There are two such factors: gaining goals (Table 20.1, column G) and openness towards the world (Table 20.1, column H).

For Kazakhstan teachers, factors responsible for overcoming crises are gaining new goals and being open to the world. Overall, such situation can also be considered as a positive tendency. For the teachers of Yakutia, among the factors evidencing the presence of crisis phenomena the highest value in 2005 was shown by the factor of losing one's reason for living (Table 20.2), and in 2015 the factor of external circumstances (Table 20.3) even though the average value was 0.3 to 0.6 in 2005 and 0.27 to 0.45 in 2015-2016.

Looking at these values, we can see that in 10 years the teachers of Yakutia become less susceptible to the influence of crisis factors. In 2015, the highest values are shown by the factors of gaining new goals and openness to the world as among 
Table 20.3 Sakha Republic (Yakutia), 2015-2016

\begin{tabular}{l|l|l|l|l|l|l|l}
\hline A & B & C & D & E & F & G & H \\
\hline $\begin{array}{l}\text { Lack of } \\
\text { future } \\
\text { prospects }\end{array}$ & $\begin{array}{l}\text { External } \\
\text { circums- } \\
\text { tances }\end{array}$ & $\begin{array}{l}\text { Lose of } \\
\text { reasons } \\
\text { for living }\end{array}$ & alienation & $\begin{array}{l}\text { Desire to new, } \\
\text { intense to } \\
\text { self-development }\end{array}$ & $\begin{array}{l}\text { Gaining } \\
\text { self- } \\
\text { control }\end{array}$ & $\begin{array}{l}\text { gaining } \\
\text { goals }\end{array}$ & $\begin{array}{l}\text { Openness } \\
\text { towards } \\
\text { the world }\end{array}$ \\
\hline 0.27 & 0.45 & 0.35 & 0.3 & 0.7 & 0.6 & 0.8 & 0.8 \\
\hline
\end{tabular}

0 - negative answer, 1 - affirmative answer

the teachers of Kazakhstan. The results show that teachers are in a stable condition: they are open towards other people and the world, they are concerned not only with their own problems but also with problems of others, their students and society, the teachers strive to resolve those problems and they feel that they belong to the society. The teachers cultivate their own abilities, change and strive to everything new.

All of the above allows them to be self-aware, to set clear goals, to make decisions and be responsible for them. Therefore, in order to neutralise the crises in professional development, the greatest significance is given to the factors of gaining goals and being open to the world.

\subsection{Conclusions}

One of the goals of the continuous professional education is the creation of platforms where teachers find the opportunity to discuss their professional work from the value-semantic content point. It is paramount for the education as the teacher who has not found personal way in understanding the mission of teaching and who is careless and blind about meaning of teaching cannot educate and bring up children, that teacher cannot nourish moral and ethical foundations. The survey aimed to identify the formation of professional competences in the context of the current requirements, compliance with professional standards for teachers, reveal qualification deficits in teachers of the Sakha Republic (Yakutia) and Kazakhstan, both urban and rural, and they, in turn, determine the educational needs of teachers in continuous professional education- training courses or retraining. From a personal perspective, the findings have shown that the questioning of the value of evaluation is shared to a certain extent in fact there are signs of discontentment among the population. However, there is also an apparent belief in the purpose of evaluation and if it is designed and implemented in a way, which motivates teachers and helps them to become better practitioners. Therefore, there is a need to forego opinions, knowing that teachers often find it a worthwhile activity, as ultimately staff improvement leads to better teaching and learning and this shows higher education quality. While teacher evaluation may have negative connotations for some, quality does not, so if everyone will aim for quality in teaching and learning, it certainly would seem a worthwhile endeavor. 


\section{References}

Amabile TM (1982) Social psychology of creativity: a consensual assessment technique. J Pers Soc Psychol 43(5):997-1013

Asmolov AG (1996) Cultural-historical psychology and design worlds. Institute of Practical Psychology, Moscow; MODEK, Voronezh, 768

Aubrey J, Coombe C (2011) An investigation of occupational stressors and coping strategies among EFL teachers in the United Arab Emirates. In: Gitsaki C (ed) Teaching and learning in the Arab world. Bern, P. Lang, pp 181-201

Chorosova OM, Gerasimova RE, Nikiforov ES, Alexeyeva FI (2006) A teacher in a changing society. 104

Deem R (2003) New managerialism in UK universities: manager-academic accounts of change. In: Eggins H (ed) Globalisation and change in higher education. The Society for Research into Higher Education (SRHE), Open University Press, Berkshire

Fullan M (2007) The new meaning of educational change, 4th edn. Teachers College Press, New York

Howard A, Donaghue H (eds) (2015) Teacher evaluation in second language education. London, Bloomsbury. 220

Howard BH, McCloskey WH (2001) Evaluating experienced teachers. Educ Leadersh 58(5):48-51

Kan-Kalik VA, Nikandrov ND (1990) Teacher creativity. M.: Pedagogika, 140. ISBN 5-7155-0293-4

Kydd L (1997) Teacher professionalism and managerialism. In: Kydd L, Crawford M, Riches C (eds) Professional development for educational management. Open University Press, Buckingham, pp 111-117

Kydd L, Crawford M, Riches C (1997) Professional development for educational management. Open University Press, Buckingham, pp 111-117

Rubinstein SL (2006) Fundamentals of general psychology. School Manag 3:27-29

Open Access This chapter is licensed under the terms of the Creative Commons Attribution 4.0 International License (http://creativecommons.org/licenses/by/4.0/), which permits use, sharing, adaptation, distribution and reproduction in any medium or format, as long as you give appropriate credit to the original author(s) and the source, provide a link to the Creative Commons license and indicate if changes were made.

The images or other third party material in this chapter are included in the chapter's Creative Commons license, unless indicated otherwise in a credit line to the material. If material is not included in the chapter's Creative Commons license and your intended use is not permitted by statutory regulation or exceeds the permitted use, you will need to obtain permission directly from the copyright holder.

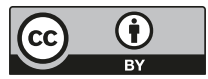

